\title{
PROVIDENSIA ALLAH DAN \\ KEHENDAK BEBAS MANUSIA
}

Parel

\begin{abstract}
Abstrak

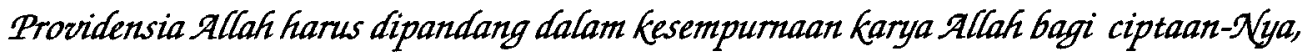
dan penggunaan KehendaK bebas manusia dilakukan di bawah Kontrol Allah di mana manusia bertanggung jawab terfadap perintah Allah.
\end{abstract}

\section{PENDAHULUAN}

Ketika Allah menciptakan seluruh ciptaan-Nya, Ia menciptakan seturut kehendak dan rencana-Nya. Tidak ada satupun ciptaan yang berada di luar dari penguasaan tangan-Nya; Ia berkuasa dan berdaulat penuh terhadap ciptaan-Nya. Khusus dalam bagian ini, penulis lebih banyak menyinggung tentang manusia sebagai ciptaan Allah.

Allah mengatur seluruh alam semesta dan yang hidup di dalamnya; Allah mengatur planet-planet sesuai dengan rencana dan kehendak-Nya, dan Allah mengatur semuanya itu untuk mencapai tujuan-Nya yang kekal.

Dari semua ciptaan Allah, Musa berkata (Kej 1:26-27) bahwa manusia diciptakan menurut peta dan teladan Allah, itu berarti manusia diberi kemampuan khusus oleh Allah melebihi semua ciptaan yang ada di bumi, manusia memiliki persamaan dengan Allah, yaitu sama-sama memiliki roh (berhakekat roh). Namun roh manusia tidak lebih tinggi daripada Roh Allah; Allah adalah Roh (Yoh. 4:24) yang mencipta roh manusia dan membentuk tubuh manusia. Jadi, manusia harus tunduk dan beribadah kepada Allah karena tujuan Allah menciptakan manusia bukan supaya manusia melawan Allah, tetapi menaati dan mengasihi Allah (U1. 6:5). Roh manusia mencerminkan hakekat Allah bahwa manusia berasal dari Allah dan Allah berada dengan sendirinya, Ia tidak dicipta tetapi mencipta manusia. Oleh sebab itu, manusia harus mencerminkan sifat-Nya dalam hal membedakan yang baik dan yang jahat. Manusia harus melakukan kehendak Allah, yaitu kebaikan. Mengapa Allah menghendaki kebaikan? Karena saat Ia menyatakan diri-Nya (melakukan perjanjian dengan manusia), Ia suka akan yang baik. KehendakNya ialah agar manusia berbuat kebaikan.

Setelah Allah mencipta manusia dan seluruh ciptaan lainnya, Ia mengurus dan merawat untuk seterusnya, dalam istilah teologisnya disebut providensia. Ia tidak 
mencipta seluruh ciptaan lalu membiarkannya berjalan sendiri, tetapi la memelihara semua ciptaan-Nya terlebih manusia. Layaknya sebuah rumah yang telah dibangun dan dipelihara oleh pemiliknya, demikian juga Allah memelihara ciptaan-Nya dan memberkati seluruh ciptaan-Nya. Dasar Alkitab yang banyak dipakai oleh para theolog adalah Matius 6:26; 10:30, bahwa Allah mengetahui segala sesuatu yang ada pada ciptaanNya dan memelihara mereka seturut dengan kehendak-Nya.

Namun dari masa ke masa, tantangan terhadap doktrin Kristen dalam hal ini semakin bermunculan dan kebanyakan ingin mengeluarkan Allah, baik sebagai Pencipta maupun Pemelihara seluruh ciptaan. Semua aliran ini selalu mengaitkan realita kehidupan dengan semua situasi yang terjadi di tengah kehidupan dan menghubungkannya dengan nasib. Salah satu aliran, yaitu Atheis Praktis. Aliran ini ingin menguji, benarkah Allah itu ada dan sedang memelihara manusia? Untuk membuktikannya mereka selalu berkata, "Jika Allah itu ada, cobalah berdoa kepadaNya dalam sesaat untuk meminta roti dan roti itu harus ada dalam sesaat secara ajaib, jika Ia tidak memberikannya dalam sesaat, maka Ia bukanlah Pemelihara dan berarti Ia tidak ada, Ia telah mati, itu berarti bahwa manusia sendirilah yang memelihara dirinya dan bukan Allah, karena hanya manusia yang mencari roti." ${ }^{11}$ Selanjutnya muncul lagi ajaran yang mirip dengan Atheis Praktis ini, yaitu Pantheisme (Pan artinya semua, segala sesuatu, Theos artinya allah), merupakan ajaran yang menyatakan bahwa dalam segala sesuatu adalah allah, yang benar-benar ada hanyalah allah. Segala sesuatu di sekitar manusia, bahkan manusia itu sendiri hanyalah penampakan saja." ${ }^{22}$ Jadi manusia itu, yang adalah penampakan Allah mampu memelihara dirinya sendiri. Ajaran ini juga sejajar dengan Gnostik. Jadi paham-paham seperti ini membuat providensia Allah itu semakin menjadi kabur, apalagi semakin banyak paham yang meragukan Alkitab sebagai kebenaran tertinggi yang menyatakan bahwa Allah memprovisensia manusia dan seluruh ciptaan lain. Ada banyak orang yang terpengaruh oleh ajaran seperti ini sehingga mereka disesatkan, belum lagi Teori Evolusi, ajaran Christian Science yang disebarkan oleh $\mathrm{Ny}$. Mery Baker Eddy tahun 1876, ia menggantikan Alkitab dengan kitab lain, yaitu Science and Health with Key to the Scriptures sebagai kebenaran tertinggi, Deisme, Humanisme, Indeterminisme dan paham lain yang telah ada dalam sepanjang sejarah hidup manusia.

Memang manusia diciptakan memiliki kehendak, pikiran dan perasaan, karena manusia diciptakan menurut peta dan teladan Allah, serta dapat bergerak dengan sendirinya, sepertinya tanpa ada Allah yang riil besertanya. Saat ia lapar, ia yang mencari makanan sendiri, saat ia sakit kepala ia mencari obat, pergi ke dokter, saat ia ingin merawat dirinya (Skin Care), dia sendiri yang mencari pemutih (Vaseline Brand Intensive 
Care Lotion), mandi susu, mencukur rambut dan lain-lain. Apalagi saat ia mengalami masalah berat, manusia tetap berusaha mencari jalan keluar, misalnya peperangan antara Irak dan Amerika yang masih segar dalam ingatan, tentu setiap orang yang ada di Irak berusaha mencari perlindungan dan harus kehilangan harta benda serta menderita kemiskinan, di mana Allah dalam hidup mereka kalau Ia bertindak sebagai pemelihara? Jadi, sepertinya manusialah yang bertindak memelihara dirinya sendiri. Realita seperti inilah yang dipakai oleh Atheis Praktis, Pantheisme dan aliran lainnya, untuk menyatakan bahwa hanya manusia yang memelihara dirinya sendiri, tanpa ada campur tangan Allah. Hidup manusia serta ciptaan lain, ditentukan oleh nasib dan usahanya sendiri. Jika manusia mau berusaha, maka ia akan terpelihara. Ditambah lagi ketika manusia ditimpa masalah, lalu sepertinya ia sendiri yang menemukan jalan keluar dan hal ini pernah terjadi pada Ayub, sampai isterinya memberi saran agar Ayub meninggalkan Allah. Di manakah Allah? Yang selalu dicari oleh orang Atheis ialah Allah bekerja secara riil dan memelihara manusia secara riil pula. Paham seperti ini tentu telah bergeser dan tidak sesuai dengan kebenaran Alkitab, tetapi terus-menerus berkembang bahkan mengobrakabrik ajaran Kristen. Ini merupakan penghambat kekristenan pada tingkat doktrin. Maka dari itu, dianjurkan agar kekristenan memiliki ajaran yang kuat dan benar-benar mamahami siapa Allah dan bagaimana Ia memelihara manusia. Apakah manusia dipelihara seperti sebuah bangunan tanpa berbuat apa-apa atau seperti robot? Ataukah ia dipelihara layaknya seorang manusia yang memiliki kehendak, pikiran dan perasaan?

Semua pertanyaan ini dapat dijawab, jika seorang Kristen memiliki pemahaman yang benar tentang doktrin providensia Allah dan ia mengenal potensinya sebagai manusia. Jika tidak demikian, maka akan mudah sekali penyesatan terjadi. Sebagai contoh, banyak orang Kristen yang hanya berdoa tanpa berusaha, bukan berarti doa itu tidak dapat dijawab Allah secara langsung seperti keinginan orang Atheis, Allah bisa saja melakukan itu sesuai dengan kehendak-Nya; Bahkan ada yang ingin menjadi Kristen hanya untuk mendapat uang, menjadi kaya karena mereka tidak mengerti bagaimana Allah memberkati semua ciptaan-Nya dan telah terjebak dengan teologi kemakmuran, mereka selalu berkata bahwa setiap orang yang menjadi umat Allah harus memiliki kekayaan harta karena Allah sumber kekayaan, namun tanpa usaha. Ada juga yang anti dengan kekayaan karena dianggap kekayaan itu hal yang duniawi, sehingga terjebak ke dalam teologi penderitaan. Orang seperti ini tidak memahami bahwa Allah juga memberkati semua ciptaan-Nya dengan kekayaan. Dalam Alkitab, terutama Ulangan 28, yang selalu menjadi ayat emas seorang dosen dimana penulis sedang belajar, bahwa pasti akan diberikan oleh Allah sesuai dengan rencana dan kehendak-Nya. 
Oleh karena ini, dalam pembahasan kali ini, penulis ingin mengkaji kembali apa yang dikatakan Alkitab tentang tindakan manusia terhadap dirinya dan pemeliharaan Allah dalam diri manusia, dan ingin menulisnya dalam sebuah karya ilmiah yang berjudul: "Providensia Allah dan Kehendak Bebas Manusia".

\section{Batasan Penulisan}

Berbicara tentang providensia Allah, merupakan sebuah pembahasan yang sangat luas. Dalam pembahasan ini, penulis memfokuskan pada hubungan kehendak bebas manusia dengan providensia Allah secara umum.

\section{HUBUNGAN PROVIDENSIA ALLAH DAN KEHENDAK BEBAS MANUSIA}

\section{Pengertian Providensia Allah}

Istilah Providensia tidak terdapat di dalam Alkitab secara eksplisit, tetapi memiliki makna implisit yang sangat jelas dalam Alkitab. Namun ketika Alkitab diterjemahkan ke dalam bahasa latin, terlihat jelaslah kata ini. Kata ini terdapat dalam Kejadian 22:8,14, saat Abraham berada di bukit Moria dan akan mempersembahkan korban, yaitu anaknya Ishak. Tetapi Allah menyediakan domba untuk mengganti Ishak. Dari sinilah konsep Providensia ini berasal.

Providensia berasal dari bahasa latin, dari kata kerja Prozidare, yang berarti memandang ke depan, melihat lebih dulu terjadinya sesuatu, dan sebab itu juga: terlerbih dulu mengambil tindakan-tindakan, terlebih dulu menyelenggarakan atau menyediakan sesuatu." ${ }^{\prime 3}$ Lalu Sudarmo menambahkan lagi, bahwa:

Providensia berarti pemeliharaan Allah terhadap segenap makhluk dan mengarahkan ke tujuan yang Ia rencanakan. Fakta ini dinyatakan dalam Mazmur 93, Tuhan adalah Raja, Ia memerintah segala makhluk (bnd. Maz. 97 \& 99). Mazmur 121: Tuhan menjaga; Ibrani 1:3: Ia menopang segala yang ada; I Petrus 5:7: Ia memelihara mereka yang percaya kepada-Nya. nJadi Allah tidak pernah membiarkan dunia seisinya, tetapi Ia selalu memelihara segala sesuatu (Mat. 10:29,30). Segala sesuatu terjadi menurut kehendak Allah, Ia biasa memakai manusia sebagai alat untuk melakukan perintah-Nya (Kej. 1:26-28; 2:15), tetapi pada dasarnya, Ia yang mengarahkan segala perkembangan menuju penggenapan rencana-Nya. Manusia harus bekerja, itulah perintah Allah, manusia diberi kecakapan untuk melakukan perintah Allah. ${ }^{4}$

Jadi, Providensia adalah pemeliharan Allah terhadap semua ciptaan-Nya yang berlangsung dalam kekekalan (rencana total Allah), Allah menyediakan bagi ciptaanNya seturut dengan kehendak-Nya guna mengarahkan ke tujuan yang direncanakanNya. 


\section{Pengertian Kehendak Manusia}

Ada baiknya mengulangi pendapat yang diungkapkan orang Atheis pada bab I, bahwa manusialah yang bertindak memelihara dirinya sendiri ketika ia membutuhkan sesuatu. Manusia yang memiliki kehendak, perasaan dan pikiran, sepertinya menemukan sendiri jalan keluar atas masalah yang dihadapinya.

Manusia memang dicipta dengan kemampuan berkehendak, berperasaan dan berpikir karena ia juga berasal dari Allah yang berhakekat Roh dan memiliki kehendak, pikiran dan perasaan (bnd. Yes. 46:10; 53:10; Maz. 139:2,17; Kej. 6:6; I Sam. 15:11). Kata kehendak, perasaan dan pikiran, sebenarnya memiliki kesamaan umum dan perbedaan khusus. Perasaan dan pikiran, yaitu kehendak dalam diri atau roh manusia, yaitu kehendak untuk merasa dan kehendak untuk berpikir. Kehendak bebas dalam pembahasan ini lebih mengacu pada pengertian bahwa perlakuan yang riil dari pikiran dan perasaan manusia, realita atau perwujudan dalam tingkah laku ke dalam dunia nyata untuk bertanggung jawab terhadap pemeliharaan diri. Jadi penulis ingin menyatukan ketiga istilah itu, dengan nama kehendak bebas. Perlu penulis tegaskan bahwa penulis tidak sedang membahas kehendak bebas yang sering disebut dalam istilah Predestinasi, karena kehendak bebas pada istilah Providensia berbeda dengan Predestinasi. Jadi, kehendak bebas dalam pembahasan ini harus dibaca dalam kacamata Providensia, bukan berarti bahwa teologi Predesitinasi tidak berhubungan sama sekali dengan teologi Providensia, kedua istilah ini sangat berhubungan erat ketika berbicara tentang keselamatan kekal, yakni Allah di dalam Yesus Kristus menyelamatkan orang pilihan Allah dan memimpin serta memelihara mereka oleh Roh Kudus. Inilah yang penulis sebut dengan Providensia secara khusus.

Definisi tentang kehendak bebas yang diberikan oleh Boland sangat menolong, Ia berkata:

Kehendak bebas adalah tanggung jawab untuk bertindak sendiri, berusaha sendiri, menyelenggarakan sendiri, baik terhadap keluarga maupun dunia sekitar, misalnya berusaha untuk memelihara kesehatan. Dalam hal ini janganlah terbius dan memperbagus kemalasan manusia karena berkata segala sesuatu yang terjadi adalah "takdir Allah atau nasib" hingga akibatnya orang bersikap pasif terhadap perjuangan, baik jasmani maupun rohani. Manusia mesti mengambil tindakan untuk hidup di hari esok. ${ }^{5}$

Pernyataan ini menarik untuk ditanggapi, bahwa kebanyakan orang terjebak dengan berkata ini takdir Allah atau ini nasibku. Bila orang menggunakan ungkapan "takdir Allah" secara demikian, maka ia telah menggantikan Allah dengan suatu ilah yang namanya "Fatum" (Sang Nasib), sehingga keagamaan hanya menjadi fatalisme belaka karena setiap orang harus menerima nasibnya. Yohanes Calvin sangat menentang 
hal ini, Ia berkata "Pemeliharaan Allah sebagaimana diajarkan dalam Alkitab, harus dianggap bertentangan dengan nasib dan kejadian-kejadian yang kebetulan karena Allah telah menetapkan dari kekal apa yang akan diperbuat-Nya dan sekarang dengan kekuasaan-Nya, melaksanakan apa yang telah diputuskan-Nya."6 Dengan istilah filsafat, nasib dapat disejajarkan dengan Determinisme, yaitu segala sesuatu terjadi menurut hukum-hukum dan sebab-sebab yang tidak berubah-ubah, yang kepadanya kemauan manusia tunduk sama sekali. Lebih lanjut Sudarmo menambahkan pengertian kehendak bebas manusia dalam hubungan dengan Providensia, ia berkata "Kehendak bebas adalah tindakan manusia sebagai alat untuk menjalankan perintah Allah guna tujuan pemeliharaan agar maksud Allah tercapai. ${ }^{\prime 7}$

Jadi dapat disimpulkan, bahwa kehendak bebas adalah kemampuan manusia untuk bertindak di bawah kontrol Allah karena bertanggung jawab terhadap perintah Allah, guna mencapai maksud Allah yang Ia telah tetapkan dalam kekekalan. Oleh karena itu, akan muncul pertanyaan, bahwa jika manusia bertindak di bawah kontrol Allah, Apakah ini dikatakan kehendak bebas? Perlu dipahami, bahwa kehendak bebas disini bertindak dengan bebas guna melakukan perintah Allah, bukan melakukan kehendak manusia sebebas-bebasnya. Untuk itu, maka lahirlah sebuah Filsafat, bahwa kehendak manusia adalah kehendak bebas terbatas oleh kontrol Allah. Permasalahan teologi yang ada dalam kehendak manusia yang selalu menjadi perdebatan adalah kehendak manusia yang telah berbuat dosa yang dicatat dalam Kitab Kejadian pasal 3 dan dikaitkan dengan providensia Allah lalu muncullah pertanyaan sepanjang masa, jika Allah tahu manusia akan berbuat dosa sedangkan Ia adalah pemelihara, mengapa Ia biarkan manusia berdosa? Semenjak Allah menciptakan manusia, Ia tidak pernah berkehendak agar manusia berbuat dosa atau memberontak melawan Dia, sebaliknya Ia berkehendak agar manusia melakukan kehendak-Nya. Ia ingin agar kehendak-Nya menjadi kehendak manusia juga, tetapi manusia memilih untuk melakukan dosa atau tidak berjalan menurut kehendak Allah, sehingga salah satu bentuk pemeliharaan-Nya ialah Ia menghukum manusia, bahkan Ia membinasakan tubuh manusia tetapi roh manusia tetap dipelihara, karena roh itu kembali kepada-Nya tetapi tetap akan dihakimi pada akhirnya. Lihatlah kasus yang terjadi pada Adam dan Hawa, Allah mengusir mereka dari Taman Eden setelah mereka berusaha melawan kehendak Allah, tetapi Allah tetap menyediakan jalan lain untuk memelihara mereka, yaitu tetap memberi mereka makan dan lain-lain, namun hubungan dengan Allah telah terkoyak dan selanjutnya dipulihkan oleh Yesus Kristus dalam Perjanjian Baru. Hal ini juga dapat dipandang dari sudut lain bahwa Allah ingin menyelamatkan manusia oleh iman dalam Yesus Kristus. Inilah bentuk Providensia 
khusus yang dikerjakan Allah bagi orang percaya, agar hubungan dengan Allah dipulihkan kembali. Sekali lagi, ini dibahas dalam Predestinasi.

\section{Tingkat-Tingkat Pemeliharaan Allah}

Ada banyak cara yang dipakai oleh Allah untuk memelihara semua ciptaan-Nya, sehubungan dengan pembahasan ini adalah manusia. Ketika Allah selesai dalam pekerjaan penciptaan, maka Ia memelihara manusia. Ada dua cara yang dipakai oleh Allah untuk memelihara_Manusia, yaitu dengan menggunakan kehendak manusia dan mujizat.

\section{Allah Menggunakan Kehendak Manusia}

Kehendak manusia dapat juga diartikan sebagai usaha. Dalam pemeliharaan Allah, Allah tidak mengidentikkan manusia seperti robot, karena robot dirancang dengan program serta diberi memori agar robot itu dapat berbertindak menurut memori itu. Namun robot itu tidak dapat bertindak di luar memori yang diberi kepadanya. Ia tidak memiliki pikiran, perasaan dan kehendak seperti manusia.

Berkaitan dengan pemeliharaan Allah bahwa manusia bertindak dan bertanggung jawab untuk memelihara diri-Nya menurut kehendak Allah. Sebagai contoh, Allah telah memberkati manusia dengan berkat umum, katakanlah berkat itu adalah uang. Pada waktu Allah menciptakan manusia, ia memberkati manusia dengan menempatkan manusia di taman Eden, tetapi karena dosa, manusia harus keluar dari taman itu dan mengusahakan tanah (Kej. 3:23). Ia harus mencari, maka ia akan mendapat. Allah telah menyediakan berkatnya dalam alam semesta ini dan manusia harus mencarinya, maka ia akan mendapatnya. Jadi barangsiapa yang berusaha pasti akan mendapat, baik orang yang tidak percaya maupun orang percaya. Bisa jadi orang percaya jatuh miskin karena ia tidak bekerja dan orang yang tidak percaya lebih kaya karena ia rajin bekerja. Yang jelas adalah Allah memberkati semua manusia dengan berkat umum, kekayaan, harta, matahari, nafas dan lain-lain, dan hanya orang percaya yang diberkati dengan berkat khusus, yaitu berkat keselamatan, seperti karunia rohani. Oleh karena itu, pertanyaan yang dilontarkan oleh orang Atheis bahwa hanya manusia yang memprovidensia dirinya sendiri benar jika dilihat dari posisi usaha manusia, karena usaha itu nyata dan dalam posisi yang berbeda ia harus bertanggung jawab untuk melakukan perintah Tuhan (konsep mengusahakan tanah) guna mendapat berkat. Tuhan sendiri menggunakan usaha manusia untuk memelihara diri manusia dan sekitarnya, karena manusia diberi kehendak, pikiran, dan perasaan. Jadi kesimpulannya adalah Tuhan memberkati manusia mencari berkat. 


\section{Allah Bertindak Melalui Mujizat}

Pemeliharaan Allah melalui mujizat telah dijelaskan oleh William Dyrness. Pemeliharaan melalui mujizat merupakan tindakan Allah secara langsung mengadakan perbuatan yang ajaib terhadap ciptaan-Nya. Bayangkan saja ada orang yang terlepas secara ajaib dari angin badai yang dasyat. Jadi pekerjaan Allah secara langsung dapat terjadi kepada semua ciptaan-Nya, namun harus diperhatikan bahwa Allah mengerjakan semuanya itu tentu sesuai dengan rencana dan kehendak-Nya. Ada banyak fakta dalam Alkitab dan kejadian-kejadian sekarang, bahwa Allah bertindak secara langsung untuk memelihara ciptaan-Nya. Contoh kejadian-kejadian seperti ini banyak diceritakan oleh Billy Graham dan juga penyelamatan Israel dari kejaran tentara Mesir dalam Alkitab (Kel. 12:29-42).

Penulis menyadari bahwa pekerjaan mujizat yang terjadi secara ajaib ini seringkali melampaui akal pikiran manusia. Allah dapat mengerjakan sesuatu yang tidak mungkin menjadi mungkin, sekali lagi hal ini terjadi menurut dengan rencana total Allah dan pemeliharaan Allah penuh dengan rahasia.

\section{KESIMPULAN}

Di akhir tulisan ini; penulis mencoba mengungkapkan hubungan antara kehendak bebas.manusia dan providensia manusia dalam kesimpulan sebagai berikut:

Pertama, providensia merupakan pemeliharan Allah terhadap semua ciptaan-Nya yang berlangsung dalam kekekalan (rencana total Allah), Allah menyediakan bagi ciptaan-Nya seturut dengan kehendak-Nya, guna mengarahkan ke tujuan yang direncanakan-Nya.

Kedua, kehendak bebas adalah kemampuan manusia untuk bertindak di bawah kontrol Allah karena bertanggung jawab terhadap perintah Allah, guna mencapai maksud Allah yang Ia telah tetapkan dalam kekekalan. Kehendak bebas manusia dalam hal ini bertindak dengan bebas guna melakukan perintah Allah, bukan melakukan kehendak manusia sebebas-bebasnya.

Ketiga, Allah memelihara semua ciptaan-Nya melalui usaha manusia sebagai alat, di mana manusia bertanggung jawab melakukan perintah Tuhan. Jika manusia bertindak tidak berdasarkan perintah Tuhan (seperti kasus Adam dan Hawa), maka pemeliharaan itu akan terganggu karena dosa. Tetapi Allah tetap memelihara menurut rencana totalNya, dan tidak ada seorang pun yang dapat membatalkan rencana itu.

Keempat, Allah juga memelihara melalui mujizat, yaitu Allah bertindak secara langsung menurut rencana dan kehendak-Nya, sehingga tingkat pemeliharaan dalam 
posisi ini masih penuh dengan rahasia karena tidak seorang pun dapat menyelami pikiran Tuhan, kecuali Ia menyampaikannya kepada manusia.

Kelima, semua masalah yang terjadi dalam kehidupan manusia, seperti kemiskinan, penyakit, dan lain-lain, pasti berawal dari kesalahan manusia atau karena dosanya. Tetapi tidak menutup kemungkinan digunakan oleh Allah, untuk mencapai tujuan-Nya dan tentu menurut kedaulatan-Nya.

\section{Endnotes:}

' Makalah Ilmu Teologi, STTJ, 2002.

${ }^{2}$ Lihat Soedarmo, "Kamus Teologi"

${ }^{3}$ Lihat Boland, Dokmatika Masa Kini, 168.

${ }^{4}$ Sudarmo, Kamus Teologi. sv. Providensia, 76.

${ }^{5}$ Kesimpulan peryataan Boland pada halaman 170-172.

${ }^{6}$ John Calvin, Institutio. (Jakarta: BPK Gunung Mulia, 1985), 41.

${ }^{7}$ Kesimpulan Soedarmo, Ikhtisar Dokmatika. (Jakarta: BPK Gunung Mulia, 1985), 116117.

\section{KEPUSTAKAAN}

Boland, B. J., Dogmatika Masa Kini, Jakarta: BPK Gunung Mulia, 1884.

Calvin, Yohanes, Institutio, Jakarta: BPK Gunung Mulia, 1985.

Feinberd, John dkk., Predistinasi E Kehendak Bebas, LRII, 1986.

Soedarmo, R., Kamus Istilah Teologi, Jakarta: BPK Gunung Mulia, 1989.

Dyrness, William, Tema-Tema Dalam Perjanjian Lama, Malang: Gandum Mas, 2001.

Sproul, R. C., Kaum Pilihan Allah, Malang: SAAT, 1996.

Berkouwer, G. C., Studies In Dogmatic: The Providence of God, Wm. B. Eerdmans Publishing, 1952. 